\title{
Writing Place after Conflict: Exhausting a Square in Sarajevo
}

\section{James Riding}

Space and Political Agency Research Group/RELATE Centre of Excellence, University of Tampere, Tampere, Finland

This essay returns to Sarajevo, a city visited by Georges Perec in 1957, employing field observation and ethnographic methods that he developed during the course of his writing career. The aim, in revisiting this city and in repeating Perecquian practices, is to move beyond the clichéd ways of seeing and writing Sarajevo only as a site of trauma and as a place defined by violence. My intention as such here is to document three days in one square in Sarajevo. Field-notes taken during this time are copied-out word-for-word in what follows. The words act as a record of the everyday-things, bodily-movements, and non-spectacular-moments, often ignored in descriptions of places defined by their traumatic pasts. Writing turned out to be a performance in-itself, as place, time and word intertwined briefly and the recounting of a present-day Sarajevo took-place. Yet through this repetitive-representational action, trauma and political-unrest re-suggested themselves. And recording place became an attempt at repairing place, in its bodily occupation of a place and in its representation of an everyday place on-the-page.

Georges Perec, Place, Representation, Conflict, Sarajevo 
Your gaze scans the streets as if they were written pages.

- Calvino, 1974, 14

Force yourself to see more flatly.

- Perec, 2008, 51

\section{Introduction}

In late July 1957 the idiosyncratic essayist, filmmaker and novelist Georges Perec left Paris for the former Yugoslavia. He was twenty-one, struggling for money, and had not yet become the writer that we now know. This Yugoslav trip would provide experiences which set in motion his journey to becoming one of the most original geographical writers of the twentieth century (see Bellos, 1993). Indeed his long-lost novel, Portrait of a Man (2014) is set partly in Yugoslavia. Despite the book being left in a suitcase for decades, it was not a piece composed swiftly like the equally forgotten L'Attentat de Sarajevo (2016). Rather Portrait of a Man is the result of three years spent shaping and then refining words on the page. The novel is written in two parts. The second part is based in the former Yugoslavia, where the main protagonist retells a story of a life, to an old acquaintance. 
Portrait of a Man though is not a book that is worth reading for its descriptions of the places in which it is set, and although it is in part autobiographical neither is L'Attentat de Sarajevo. So in a sense, in this essay, I travel with the now well-known Georges Perec back to Yugoslavia - to a place which gave birth to his constrained ethnographic and geographical writing (see Becker, 2001; Phillips, 2016) - to contemplate what he might possibly have written about this place had he not died in 1982.

It is common to create a certain historical and geopolitical narrative in order to write of the former Yugoslavia. Work draws on either ethnographic field data collected to explore state-building and post-conflict reconstruction (see e.g., Jeffrey 2006), or, through a form of discourse analysis, work interrogates the loss or dispossession of identity, deconstructing the internal skirmishes of ethnic and identitarian debate (see e.g., Campbell 1998). Channeling Perec and drifting somewhat against the more spectacular or established geopolitical discourses associated with research on the collapse of Yugoslavia (see Campbell, 1998; Crampton, 1996; Glenny, 1992; Little and Silber, 1996; Rieff, 1995; Thompson, 1992; Riding, 2015a), the post-socialist transition era after Yugoslavia (see Arsenijević, 2010, 2011, 2014; Bennett, 2016; Bieber, 2006; Campbell, 1999; Horvat and Štiks, 2014; Jeffrey, 2012; Toal and Dahlman, 2011; Riding, 2016a, 2016c, 2017), and the Balkans more widely (see Carter, 1977; Glenny, 1999; Goldsworthy, 1998; Mazower, 2002; Todorova, 1997; Žižek, 2000), this first-hand account of a square in Sarajevo witnessed over three days follows instead the trail of 
another, more "essential" or "everyday" geography (see de Certeau, 1984). In so doing the experiential narrative produced, speaks back to Perec's work and his attempt at exhausting a place in Paris (see Perec, 2010, from 1975 original in French), and also to a form of non-representational (see Thrift, 2008), embodied (see Ingold, 1993), landscape geography (see Wylie, 2007), which has emerged in the past decade and a half dealing with performance, memory, and aesthetics in-place, yet it relocates this work to a region of the world where in which it perhaps seems to some to be out-of-place (see e.g., Daniels, 2012; DeSilvey, 2006, 2007, 2010, 2012; Dewsbury et al, 2002; Dubow, 2001, 2011; Edensor, 2000, 2005, 2008; Jones, 2005; Lorimer, 2003, 2006, 2012; Lorimer and Wylie, 2010; Matless, 2008, 2010, 2014; Pearson, 2006; Riding, 2015a, 2015b, 2016b; Rose, 2012; Wylie, 2002, 2005, 2007).

It is clear that the Sarajevo we think of, write of and remember today, is not the one that Perec observed in 1957. The Sarajevo of today is known and enframed via the Bosnian conflict and its enduring aftermath, and the discursive designators of place are here drawn from a Western imaginary geography of the Balkans (see Goldsworthy, 1998; Todorova, 1997; see also Berger, 1972; Cosgrove, 2001, 2008; Cosgrove and Daniels, 1988). A repetitive Balkanism takes place, where the place is viewed through an idea that the Balkans is a place of immutable ethnic hatreds outside of a cosmopolitan Europe: a place of mindless slaughter on formless ground (see Toal, 1996). This imagined Balkans can be found in the opening lines of Misha Glenny's (1999) magnum opus, The Balkans, 1804- 
1999, where Bram Stoker's (1897) Dracula is said to be representative of an almost gothic region. In the old Orientalist tradition, it seems as if the Balkans occupies the centre of some sort of imaginative whirlpool, where every known superstition in the world is gathered (see Glenny, 1999).

Echoing the well-established literature on representations of the Balkans in literary studies and geography - such as Inventing Ruritania (Goldsworthy, 1998) and Imagining the Balkans (Todorova, 1997) - Mark Mazower (2002) details how this has come to be the case. Mazower (2002) argues that representations of the Balkans loaded the Balkans with negative connotations: inharmonious conditions, small antagonistic states, and hostile nationalities, all of which conspired to form the intractable Balkan or Eastern question (see also Carter, 1977; Glenny, 1999; Goldsworthy, 1998; Horvat and Štiks, 2015; Todorova, 1997). Writing of the Balkans as Europe's ghost, Slavoj Žižek (2000, 12) goes further. Down there, always somewhere a little further to the southeast, the formerly socialist Balkan states are a photographic negative of what was until recently a tolerant, multicultural, post-political, post-ideological Europe. A "postmodern racism" exists, Žižek argues, where an imaginary Balkans is constructed as the intolerant other, while the rest of Europe has supposedly come to terms with otherness in its much vaunted - indeed marketed - language of cosmopolitanism and multiculturalism (see Žižek, 2000, 1-2). It seemed in light of this stubborn symbolic register, an important task for a geographer to once again wander through Sarajevo, following Perec, and to write of its 
squares and streets, in order to attempt to move beyond the casual naming of the city as a site of trauma and as a place defined by violence (see Nancy, 2000).

Importantly for this essay, in An Attempt at Exhausting a Place in Paris (2010, from 1975 original in French), Perec leaves the reader with the impression that any record of a place can never be truly complete (see Hobbs, 2015). Amidst his precise record of bus arrivals and shop openings - documenting the infra-ordinary rather than the historic - are singular events that undermine the very idea of total explication (see Perec, 2010). It is the incompleteness of any attempt at exhausting a place that is a vitally important counternarrative in places defined by their pasts, places that seem as if they can only ever be written as a site of war. Places that can only ever be researched through the gaze of an elevated, distanced, geopolitical eye, unearthing historical stories and pressing into their surfaces certain geopolitical narratives (see Toal, 1996; see also Berger, 1972; Cosgrove, 2001, 2008; Cosgrove and Daniels, 1988). The aim as such, in revisiting this city and in repeating Perecquian practices, is to move beyond the clichéd "ways of seeing" and writing Sarajevo only as a site of trauma and as a place defined by violence (see Berger, 1972; Cosgrove, 2001, 2008; Cosgrove and Daniels, 1988).

Yet importantly, this essay is not a denial of a traumatic past and its enduring traces that affect the lives of Sarajevan citizens and the politics of present-day Bosnia (see Riding, 2015a, 2016a, 2017). Rather it seeks to question how places are continually framed as 
sites of mass murder, siege, and also it deconstructs in-place the seeking out of traumatic stories in order to reinforce a pre-existing idea of a place (see Hemon, 2013; Jergović, 2004). Here, in contrast to much recent geographical writing, which has sought to define the view of the self in a location in terms of presence in various forms, seeking out absentpresences that are "haunting" spectral traces, I aim instead through a Perecquian geographical practice to describe another more "essential" or "everyday" Sarajevo (see Wylie, 2009, 278). For “dreams of presence”, as Mitch Rose $(2006,538)$ has argued previously, are a common strand in much of the geographical literature that emerged after the "new cultural geography" which describes a place or a landscape, where the geographer presses a narrative of "ghostly presence" into the material scene ahead (see Cosgrove, 1985; Cosgrove and Jackson, 1987; Cresswell, 2010). As John Wylie (2009, 278) writes, citing Rose (2006, 542), this work hinges upon a Derridean "impossible possibility" and it remains a "dream".

\section{Approaches to What?}

"In our haste to measure the historic, significant and revelatory, let's not leave aside the essential: the truly intolerable, the truly inadmissible", writes Georges Perec $(2008,209)$ in an essay called Approaches to What? It matters to Perec that the questions he asks, barely indicative of a method, let alone a project, seem trivial and futile. This is precisely 
what makes them essential, this is precisely why they matter more than so many of the other kinds of questions we have tried to ask, or been trained to ask. In Place Saint-Sulpice, a square in Paris, he sits in one café then another for three days, recording "everything" that passed his field of vision (see Perec, 2010). As such Perec's Tentative d'épuisement d'un lieu parisien, an attempt at exhausting a place in Paris, aims to describe all the things that usually go unnoticed (see Perec, 2010). It is an attempt to document what he had previously called L'infra-ordinaire - the infra-ordinary - the background noise, the habitual, the stuff that is looked over, missed when gazing at a place (see Perec, 2008, from 1974 original in French). And is, as such, a critical examination of what draws and escapes our attention. I take Perec seriously here and I borrow his "way of seeing" when sat in a square in Sarajevo, recording the minor details of the scene and the "small stories" of the ordinary people present here (see Berger, 1972; Lorimer, 2003).

For, the summoning of "ghostly presences", as is done in cities such as Sarajevo and Berlin, can lead to a speaking-for and an over-writing of the embodied everyday practices that take-place in the cities themselves, and indeed it in part sanitises a traumatic past, decentering the human from a place (see Maddrell and Sidaway, 2010; Till, 2005, 2010). Whole places are imbued with a human agency, as if through a ghostly register, the bricks and mortar can actually speak for the dead, and the dead are as such used in post-conflict places to talk of an affective atmosphere or a landscape of death. The survivors are in addition merely haunted specters, and are further narrativised to create a spectral 
geography of the haunted post-conflict city. As such, in this essay, I want to further practice in post-conflict places, so that instead of searching for traumatic stories, "mapping spectral traces", and pressing a narrative of the haunted deathscape, or traumatised cityscape into Sarajevo, I attempt to advocate another more grounded or “everyday" geographical writing practice in post-conflict places (see see Maddrell and Sidaway, 2010; Till, 2005; see also de Certeau, 1984).

For obliquely, through a Perecquian geographical practice we see a place as it is in the present, we recognise its rhythms, its chaos and order. In short, we see the present as well as the past, the place and not only the coating of usual signs. And through a repetitiverepresentational action, as is undertaken here in a single square over three days, trauma and political-unrest are re-suggested, not overlaid as is commonplace (see Lefebvre, 2004). Writing of seemingly incidental moments and remembering the little details of a place - a location, an apartment, or a bus journey - enables a series of associative memories to occur, memories that are not aligned to a singular narrative of the traumatised place. Indeed, in Freud's early writings on trauma, this form of mapping or placing trauma, through memorial acts, is specifically seen as a way to allow a traumatic event to be "forgotten" (see Riding, 2016c). As such, the field-notes taken in a square in Sarajevo are copied-out here, word-for-word, in what follows. The words act as a record of the everyday-things, bodily-movements, and non-spectacular-moments. And recording 
place, became an attempt at repairing place in its bodily occupation of a place and in its representation of an everyday place on-the-page.

This reparative intention, via a Perecquian writing of place, is in this essay positioned as an "appropriate gesture" undertaken in-place after conflict (see Taussig, 2006). Yet, a feeling persisted as I sat in a square in Sarajevo, witnessing a portion of place over three days. A feeling that the appetite for a written geography of the post-conflict place is of a vulgar or low appetite. And that it is, in some way implicated in a "commercial ghoulishness" (Sontag, 2004, 100). Violence is a spectacle, the very thing which characterises our age, and it feels disrespectful to be captivated by its strange charisma. It really amounts to a kind of gawking at pain, death, trauma (see Taussig, 2006). And "the unpleasant corporeal remainder... the excess of scattered bones, the dead-but-alive organic matter, whose smell builds up like a thick reside and clings to the rooftop of your mouth", is sanitised (Arsenijević, 2011, 166). This remainder itself $i s$ expressionless (see Benjamin, 2016). Yet, I want to bear witness to this remainder after conflict, to evoke place after conflict, and the real leftover remnants of conflict in-place, necessarily returning the "everyday" to the writing of post-conflict places (see Riding, 2016c).

Indeed, one of the reasons for deploying a Perecquian perspective is the "flat description" or "everydayness", it encourages (see Toal, 1996). This form of constrained description, is a significant antidote to the "trauma-spectacle" which has arguably become the 
dominant way of attending to the landscapes of "trauma-sites" like Sarajevo, or Berlin. In a direct critique of the spectacular, the mournful, the Romantic, Perec is primarily concerned with simple, plain description, the small things that he notices, his immediate world, and the present-day material landscapes that surround his body. His work is inherently geographical, and as this essay demonstrates, human geographers could further apply his work in the field (see Phillips, 2016). For Perec's texts concern space and place, and of relevance to this essay, his texts obliquely attend to landscapes of memory and trauma - as in the spectral cultural geography cited by Wylie (2009) and Rose (2006), though in a different register - amongst other things.

\section{An Appropriate Gesture}

The "appropriate gesture" that this essay performs in Sarajevo following Perec (see Taussig, 2006), opens out on to and speaks to the generative affordances of a Perecqian sociology, written of previously by Howard Becker (2001). Indeed, Becker's (2001) article, "Georges Perec's experiments in social description", is a central text with which this "experimental" essay seeks to engage. For as can be seen in this account, following in the footprints of Perec, the devices in Perec's repertoire include minutely detailed descriptions, lists, the use of imperfect and conditional tenses, significant but mundane exemplars. And in Becker's (2001) sociological reading of Perec, this demonstrates the 
necessary tensions between the presentation of detail, the role of generalisation, and the need for explanation in our "tellings about society". He argues that Perec's key works of the 1960s and 1970s can be understood, in different ways, as forms of ethnographic writing, utilising approaches, methods, and stylistic devices, which remain highly pertinent to ethnographic practices today.

This secondary literature on Perec and his work, in the social sciences and in the humanities, often surrounds the "productivity" of a Perecquian perspective for critical social and cultural analysis, when undertaking "experimental" ethnographic fieldwork (see Phillips, 2016). Engagements with Perec's most accomplished and sustained field texts, An Attempt at Exhausting a Place in Paris (2010, from 1975 original in French) and Species of Spaces (2008, from 1974 original in French), focus upon the playfulness of Perec's work, his attention to the ordinary, and writing as a fieldwork practice (see Phillips, 2016). Yet I would argue, that few have attempted to inhabit a Perecquian sensibility completely, and in addition, attempting to exhaust a place in Sarajevo is arguably more productive than in other sites. For here, following Perec, history is not presented as an explanatory prism, rather a necessity for seeing the actuality of the material geography of the city of Sarajevo and its inhabitants. As such, this essay asks the reader to weigh up the immediacy of the itemising that Perec undertakes in his "fieldwork", alongside the reflexive moments of anecdote and certain historical 
references present in his texts. In this essay, these rhetorical shifts work to challenge the privileging of any single form of geographical description.

It is through this shifting, that a sociological "productivity" of Perec and a Perecquian geographical description is explored in-place. And there yet might be a number of productivities that a Perecquian practice can offer different kinds of spaces. For while the "flat description" or "experimental fieldwork", undertaken in this essay is the same kind of ethnographic work that Perec undertook in Paris, it is given a different sense of urgency in Sarajevo. Where in which, it is performed as a vital political choice to write of the present rather than through the common registers of the past. As such, there remains a question that this essay cannot answer completely. That is, could you borrow from Perec and do this kind of "experimental" ethnographic fieldwork anywhere? Or, is it necessary to place Perec in contradistinction to the use of the spectral, the mournful, the Romantic? For as Richard Phillips $(2016,5)$ has written, a sustained geographical reading of Perec is lacking, despite some promisingly Perecquian work (see Garrett, 2013).

Indeed, what sort of epistemological affordances are enabled in the following of Perec for the geographer that this essay has missed? And - with this possibility of a future Perecquian geographical practice in mind - is it a worthwhile exercise for a geographer to follow Perec? For as Maurice Blanchot (1989) tells us in The Space of Literature, reality always disappears in its writing, as this is an essential structure of writing - even 
if we abandon ourselves to what we witness. The present has always already passed and is always yet to come. And there is in this sense a presence-absence in all writing, a form of negation. As such, the idea that a geographer could provide a fragmented window onto a city is an impossibility, a Derridean "impossible possibility" (Wylie, 2009, 278). It too remains a "dream" of presence (see Rose, 2006, 542), merely an attempt to write the present. For this is after all, an attempt at exhausting a square in Sarajevo, as it was for Perec in a place in Paris. Yet, it is still a vital attempt to describe the present in a place defined by its past, where the absence of a present, the without present, is perhaps understood more keenly than it is elsewhere (see Blanchot, 1989).

\section{An Attempt}

LOCATION: Café Liberty, Trg Oslobođenja

DATE: Tuesday $17^{\text {th }}$ May 2016

TIME: 10:15 a.m.

WEATHER: Some clouds, mostly sunny

What can I see here?

There are three women chatting to my left, they move on and leave the square Further to my left there is a group of men playing chess. 
A man with a dog leans down and picks up a bottle of water,

Taking it out of a plastic bag he was carrying, removes his coat and sits on a bench.

Two pigeons,

Two tourists taking photographs of the men playing chess.

To my right is a near continuous flow of people,

They walk mostly in straight lines up and down Ferhadija

Keeping to the left of the street or the right of the street, depending on which direction they are walking in.

A woman with a bag that she pulls along quickly turns around and returns in the same direction from which she came - seemingly remembering something,

Two dogs play in the bushes, just over my left shoulder

One is on a lead, so can only circle its owner, the other belonging to the man sat on the bench bounces around in all directions

Then becomes bored and lies down in a patch of sunlight, breaking through the branches.

I attempt to count the number of men playing chess.

An elderly gentleman walks past carrying a child

A young woman in a headscarf passes by, followed immediately by another young woman in sunglasses and a fur coat. 
I guess around ten people pass me every ten seconds to my right - along Ferhadija.

Almost directly ahead of me is a man selling sunglasses, things that blow in the wind, and children's toys and within my immediate vicinity is the shop Benetton - occasionally people go in through the glass doors to look at the clothes.

Two pigeons sit on the roof of a little hut that sells paintings of local landmarks - one pigeon has scruffy feathers.

The mass of people watching chess has grown

The chess pieces are now barely visible from where I am sat.

A man smokes a cigarette, spits, removes his hat, and scratches his head

A tanned gentleman to my right walks quickly carrying a folder

A woman with bright orange hair and a leather jacket follows,

Four more leather jackets

A group of four women - all wearing leather

In fact, I notice another five leather jackets in quick succession.

An elderly woman with white hair wears a grey suit and looks very smart

A man undoes the buttons on his cuffs and hangs his jacket over his right shoulder

A man with a beard and a beany hat is on his mobile phone

Two men eating burek look at the paintings hanging in the little hut in front of me. 
A child attempts to play with the dogs to my left, still laid in the sun

The boy is pulled away by a woman, who I presume is his mother - the boy screams angrily.

Most people are dressed in warm clothes, despite the sunshine

A woman walks past to my right wearing a heavy blue overcoat.

Another dog

This one has speckled fur

It sits with the others, now in the shade.

Two men chat in the street and block the flow of pedestrian traffic

A woman walks over towards me to feed the speckled dog

A woman with a walking stick and yellow beads - a bead necklace - stops

Looks at the paintings - others loop around her speedily.

A man looks directly at me - he is wearing a coat similar to mine.

The waitress looks over my shoulder

I am now aware of where I am

The music from the café is audible.

A boy chases some pigeons, they scatter

Another boy follows - they both shout as they run. 
A woman with one leg, who is usually stood begging by the pomegranate juice stall, goes past on crutches with a friend

A man recognising her stops to give her some change.

The gathering of pigeons to my left has grown considerably

They are merging with the group of dogs and the man sat on the bench

Pigeons scatter

The dog - speckled dog - stands up on hearing the clapping wings

And then collapses down again.

A woman in a sun hat points to the other side of the square

A man quickly darts into the square after it initially looked as if he would continue down Ferhadija

Some smartly dressed tourists travel by towards the Baščaršija

A small girl points at the speckled dog

A man ties his shoelace - in a way that only middle-aged men can do, hoisting his leg up onto a ledge

The young girl chases the speckled dog away

She seems sad that the dog left and continues to follow the dog

Her father - I guess - picks her up and puts her on his shoulders.

A man with blue lensed sunglasses eats an ice-cream 
A couple kiss - well a man kisses a woman on the cheek as they walk.

I hear a brush - then I see a woman sweeping.

Another woman who would like to order a coffee speaks to me - a friend joins her.

I hear the bells of the church

It is 11:00 a.m.

A bird lands really close by and chirps a few times - then flies away.

Break.

\section{LOCATION: Café Liberty, Trg Oslobođenja}

DATE: Tuesday $17^{\text {th }}$ May 2016

TIME: 11:15 a.m.

What has happened in the fifteen minutes since I was last writing?

I remember a man with a large number forty-seven on his t-shirt

A young boy was attempting to sit on a bench when it flipped up and trapped him - his father came over to help him

A man was shaking whilst eating an ice cream

The woman who was sweeping up, swept everything that she could into a dustpan around my feet 
And a dog with a fringe passed by trailed by its owner.

That is what I can remember.

Two clusters of people are now standing on my right, blocking Ferhadija

They are waiting for a walking tour of the city to begin

The two clusters join together - making it difficult for anyone to pass now

A woman breaks from the crowd and begins to talk

She speaks German.

Two pigeons wander over

One bullies the other, following closely behind, forging a trail as they dart around in unison - why not fly away?

The crowd moves on, and continue their tour of the city elsewhere.

I can see the whole square again now - can my view ever be considered whole?

I recognise a photographer - he passes to my right

I try not to catch his eye - though I think he sees me sat here.

The two girls to my immediate right in the café are now three girls - they talk almost continuously

Occasionally they seem to wonder what I am doing - or do they? 
It is 11:30 a.m., I hear the church bell, and I also hear some hammering.

A bedraggled little bird perches on a small wall next to me

It alters my gaze to that which is closer

What is actually around me?

I have been scanning the square so far.

Within two metres of where I am sitting outside on a table in this café is

A glass of orange juice, and the bottle it was poured from

A cappuccino in a cup and saucer

An ashtray

Two receipts

A chair sits empty opposite

Three girls sit around a table to my right

The stall in front has six paintings that I can see and another twenty that I can see the back of through the thin metal wire construction that displays them to onlookers.

On the floor, are stone flags, with cigarette ends pushed between their edges and down into the cracks

I can see some half eaten oranges

Some litter, including a packet of sugar

And a flyer, which seems to be advertising a supermarket. 
On the pole holding up a giant umbrella - partly enclosing the café customers from that which is outside its demarcated boundary - there is written on a small sticker

SUMAN

SUNCOBRANI I TENDE

Model: KONZOLNI SUNCORBRAN

The fabric above my head, which makes up the giant umbrella providing shelter, has COKE ZERO written all over it

And at the top of a lamppost almost within arm's reach, is a metal sign containing the following words

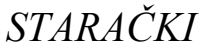

$D O M$

$D G$

\section{GREEN}

A paper sign, which somebody has taken the time to attach to the lamppost at eye height, is mostly indecipherable as it has been torn off,

Uštedite Svoje Vrijeme!

$60 \min =10 \mathrm{KM}$

Kontakt na brojeve:

A man bumps my chair as he sits down. 
I decide to move on.

Break.

LOCATION: A bench, Trg Oslobođenja

DATE: Tuesday $17^{\text {th }}$ May 2016

TIME: 2:00 p.m.

I took a short walk down Maršala Tita

Then looped back around past Trg Susan Sontag, Pink Houdini Jazz Club, Štrosmajerova, Hotel Europe, through the Baščaršija to the Sebilj - an ornate drinking fountain in what is nicknamed Pigeon Square due to all the birds - and back up Ferhadija to reach the relatively nondescript square, Trg Oslobođenja, or Trg Alije Izetbegovića. On my way, I had a Leffe Blonde at City Pub and flicked through a copy of the anti-Nazi newspaper Oslobođenje. I found out later that the newspaper had, during the war in Bosnia and the Siege of Sarajevo, operated out of a makeshift newsroom in a bomb shelter after its tenstorey office building had been destroyed. During the war in Bosnia, its staff, consisting of Bosniaks, Bosnian Serbs, and Bosnian Croats, managed to print the paper every day, except for one

- Oslobođenje means Liberation in English.

I can see the chess pieces on the ground A man squats next to the black castle 
He is wearing a red jumper

One of the players wears a blue baseball cap

He is carrying a folder underneath his left arm and wears a black leather jacket.

Directly to my right is a memorial

It is made from white stone

Brigada Policije 1992 is engraved at the top, above a list of names and dates.

A flag files,

A white background with a shield in the centre

A blue shield with a yellow line drawn diagonally across it

Six symbols float either side of the diagonal line.

A woman coughs or sneezes into a handkerchief whilst smoking a cigarette

Another woman pushing a pram walks towards me and then turns back in the opposite direction

There is a group of people waiting for the next bus.

A man with a yellow folder walks past

A soldier walks past - in full uniform

A man comes over, shakes my hand and asks for a cigarette - I don't have any

A yellow bus goes past - I can't see the number. 
I focus on the chess.

A bishop wobbles, as the chess players set up the board

Painted on to the ground of the square

I can smell the perfume of two young ladies, wearing tight stone wash jeans.

A man playing chess is wearing a big hat, he also wears cowboy boots

A woman walks past eating a lollypop

I notice again the pigeons.

A woman sits next to me

She talks to the pigeons as they crowd around her feet.

Break.

\section{LOCATION: Church, Trg Oslobođenja}

DATE: Tuesday $17^{\text {th }}$ May 2016

TIME: 4:45 p.m.

Leaving the square again briefly, I walked to Celtic Pub, a smoky bar where Sarajevans wear kilts, and striped Glasgow Celtic Football Club shirts hang on the walls. I ate cevapi at Cevabdzinica Nune next door to the pub. 
I saw on my way to the pub the usual scenes of Sarajevan life, a couple of benches with fresh produce for sale, tomatoes etc., a pomegranate juice stall in the corner of the square, a group of three policemen, and outside in all of the cafés, young men and women, smoking and drinking little coffees, usually espresso with a tap water. I saw the odd tourist randomly snapping everything with their cameras. And as I turned left into the alley way leading to Celtic Pub and Cevabdzinica Nune I stepped over a Sarajevo Rose - a concrete scar of a mortar shell explosion, later filled with red resin that look almost like floral arrangements, unique to a city that was a site of intense urban warfare. I didn't see a tram. I did though see the guy who sells pens. He walks around pubs, restaurants, and cafés, selling the pens, which have a Bosnian crest stuck to them. I did not bump into anyone I knew, any friends, as most of them have left the city for jobs abroad - Bosnia has the world's highest recorded youth unemployment rate.

I am sitting on a bench at the entrance of the church,

Facing away from the majority of the square,

In the shade beneath a tree.

A slow and steady stream of people pass between the bench, where I am sitting And the entrance to the church.

A lady walks into the church carrying a big bag on her shoulder.

A blue moped is parked in front of the gate to enter the church grounds 
I focus on the road to my right

A black car passes.

I hear noise coming from the fast food place called Vanni.

A boy swings back and forth on an exercise machine - using it not for exercise but amusement instead.

The sun goes in.

A map of Sarajevo hides a large part of the road from view

Three white cars pass by, one after the other

Then a black one.

A couple sit on the bench opposite.

It seems quieter - away from Ferhadija.

Kolor Knjižara Pro Credit Bank Podroom

Bella Cantina Fotokopiranje Printanje Spiralni uvez

Some words that I can see.

People wander into the church - I wonder if there is a service about to take place. Behind me, I presume the square is still busy and individuals continue to walk up and down Ferhadija. 
It is 5:00 p.m. - I hear the church bells.

The bells continue to ring out for longer than they usually do, as a woman walks past with five boxes of shoes - she later comes back with no boxes.

End.

\section{LOCATION: Middle of Trg Oslobodenja}

DATE: Wednesday $18^{\text {th }}$ May 2016

TIME: 10:08 a.m.

WEATHER: Blue sky, some wispy clouds

It is 10:08 a.m.

Most of the people present stand still and some bring their hands towards their chests, for the Bosnian National Anthem. The men stop playing chess and turn towards the white memorial. I hear policija, stari grad, Sarajevo and then the names of dead police officers are read aloud. A violin begins to play.

The bell of the church tolls - it is 10:15 a.m.

A circular saw whirs, drowning out the voice. The crowd watching on is roughly sixty or seventy strong. A woman clearing bins begins to rake grass beside me - she has recently cut it with a scythe. The circular saw continues over the speech. 
It is now 10:20 a.m.

The chess players begin to set up for the next game.

A couple of tourists look bemused - they take photographs of the chess.

I hear the word sloboda - freedom in English.

A young person begins to speak.

The circular saw again

A white knight is moved, followed by a black bishop

Two pigeons swoop down

Clapping.

People walk past without paying attention to the memorial service

A white knight is moved, followed again by a black bishop

I hear a police siren.

Break.

LOCATION: Café Monolog, Trg Oslobođenja

DATE: Wednesday $18^{\text {th }}$ May 2016

TIME: 10:35 a.m.

It is $10: 35$ a.m. 
I notice the speckled dog from yesterday

The square is obscured from view by a sign for Strongbow cider $-U$ Svijetu.

I can see the woman in green dungarees, who was raking up grass only a few minutes ago.

The word PARK is written on the back of her outfit. She continues for a while to sweep grass onto a plastic tarpaulin with a rake.

A soldier walks past.

What has changed about the square since yesterday?

The speckled dog is still here

People wander up and down Ferhadija,

And all the things that were here yesterday still appear to be here.

An ice cream stall

A pomegranate juice stall

A stall selling paintings

Three banks

A shoe shop

Three or four coffee shops - if you include Michelle, which is on the corner of the square A church - the bell tolls as I write church

A 7D cinema box - whatever that is?

Some yellow exercise machines 
A sports shop, which is being refurbished - the circular saw

A map of the city - the Stari Grad

Around twenty benches at a guess

A bus stop

Some loops to lock a bicycle to

A newsagents

A tobacconists

- Both the same to look at, but with different goods

A chess board painted on to the stone flags which cover the ground of the square

A statue at the centre of the square - a man reaching up and putting together what looks like the beginnings of a globe, remaking the earth

Dotted around the square are the busts, or heads on pedestals of around twenty notable dead people

There is a book shop

A little opening selling stuff that blows in the wind, sunglasses, and children's toys And there are around fifteen bins.

It takes one hundred and ten steps to walk from the road where the buses pass by to Ferhadija, and about one hundred and five steps to walk from the Economics Faculty to the pomegranate juice stall which sits on the corner

So it is a square, more or less, the same whichever way you flip it. 
It is 10:51 a.m.

I see the owner of the hostel I am staying in - Residence Rooms

He nods his head at me.

Break.

\section{LOCATION: Various, Trg Oslobođenja}

DATE: Wednesday $18^{\text {th }}$ May 2016

\section{TIME: 12:40 p.m.}

Nina Babić - a local jazz singer, who sounds a bit like Amy Winehouse - came over to the table at which I was sitting. Nina plays at Club Monument on Štrosmajerova every weekend in a band called Sunday Stories. She explained that she plays there now after falling out with Beko, the manager of the Pink Houdini - Beko is a Bosnian who spent a long time in Sweden and is heavily involved in a protest movement, which began in Sarajevo in February 2014, when the presidency building was torched and the city briefly resembled a war zone. Nina offered me some Drina cigarettes, in the paper packet - which are apparently as close as you can get to the old Sarajevo Marlboro, the best cigarettes in the world. I had a couple of the cigarettes with a Bosnian coffee. Nina gave me a telling off for not telling her I was in town, and seemed surprised when I explained my selfimposed task was to write about this square - why this one?

I am writing and moving for the first time. 
I focus with each step on another thing, or a person, or on one of the many momentary events that are occurring here.

There are two dead looking pigeons beneath a tree - they could just be curled up in the shade, although they are very still.

There is a manhole cover

Two girls push down a bench and sit on it

I see a bottle top beneath my feet in the grass

And there are four trees in this patch of the square,

A large bird eats something and wanders towards me

Four smaller birds congregate, then zoom off.

There is an island of yellow flowers in the centre of this island, entity, or newly defined smaller space within the original square - the only flowers growing in the entirety of the original square.

The pigeons wake up, as the big bird passes by

The church bell tolls - the church is directly beside this smaller square, a presence that casts a shadow on occasion.

A yellow bin is present - Dogs Trust

TREMOR - written in black marker pen 
A pigeon appears to be caught in some winding branches

There is a bust missing - Isak Samokovlija, 1889-1955

Just the pedestal remains

On a lamppost is

\section{Cijena Po Dogovoru}

I have now become completely disinterested in this de facto square within the larger square.

I see on the floor a packet of cigarettes

Pušenje ubija

Pušenje ubija

Пушене убија

Smoking kills

Smoking kills

Smoking kills

Bosniak

Bosnian Croat

Bosnian Serb

End.

LOCATION: Bus Stop, Trg Oslobođenja 
DATE: Thursday $19^{\text {th }}$ May 2016

TIME: 10:15 a.m.

WEATHER: Blue sky, some large clouds

Jingling keys in a hand

Mobile phone held to ear

Car engines

Sunglasses

Beard.

White queen is taken

Silver Vauxhall Corsa

Grey BMW

Red VW Golf
Tight jeans

Shouts from the chess board

Alarms

Leather jacket

Beep of a car horn

Green Renault Twingo

White VW Golf

Silver VW Polo

Circular saw.

A woman checks the time on her watch.

White Vauxhall Astra

Silver Mercedes

Running man

Jingling keys

Circular saw.
A soldier

White VW Passat

Confused man

Flapping of wings 
Blue Mercedes

A man on a bicycle

Meggle Gastro

The clicking of a lighter

Circular saw.
Black Audi

An Alfa-Romeo

Tourists watching chess

A soldier in a bulletproof vest

The church bell tolls - it is 10:30 a.m.

A yellow bus arrives

Twingo

A white bus arrives

A woman shuffles her feet

Circular saw.

A packet of crisps is opened

VW Golf

Lumberjack shirt

A child screams
Yugo

Someone just catches the bus

A car door closes

The white bus leaves

Taxi

Red Mercedes

Crisps are eaten

Silver Skoda

Circular saw.

I hear and see greetings and meetings of people constantly across the square, mini-events, moments in time, making it impossible to describe them all, all the routes taken, all the expenditures of energy, all the accidental collisions, and all the planned trajectories. 
The sun goes behind a cloud - sending the square into relative darkness, as all the colours of the square are dulled, or perhaps the opposite.

A man sits next to me.

Break.

\section{LOCATION: Café Monolog, Trg Oslobođenja}

DATE: Thursday $19^{\text {th }}$ May 2016

TIME: 12:30 p.m.

I walk further away from the square today, down Ferhadija, towards Maršala Tita and the eternal Yugoslav flame - a memorial to the military and civilian victims of the Second World War in Sarajevo, dedicated on the $6^{\text {th }}$ April 1946, a year after the liberation of Sarajevo from the four-year-long occupation by Nazi Germany and the fascist Independent State of Croatia - until I reach the new glass shopping centre, the BBI Centar. I continue further, past parliament, almost as far as the Avaz Twist Tower - a 176m skyscraper finished in 2008 - before I turn left near the Holiday Inn - built for the 1984 Sarajevo Winter Olympics, where Torvill and Dean won gold, familiar to many around the world, as news reports were filed from the yellow, ochre, brown and grey hotel by journalists during the Seige of Sarajevo - past a tram, the museum - seemingly always closed - away from sniper alley and the U.S. Embassy, to the bridge where the first victims of the war in Bosnia were killed, crossing the Miljacka. I head along the riverbank 
towards the Latin Bridge - where Gavrilo Princip assassinated Franz and Sofia Ferdinand, the shooting that would lead to World War I - before making a right to sit for a while at Kino Meeting Point and travelling back to the square.

A crying child.

It is just after 12:30 p.m.

A police officer checks what I am up to - and seems OK with it.

Wind - a storm is coming.

I look out across the square from my position on its edge, an outsider. I see similar things, perhaps even the same things, the same pigeons, the same people, the same cars and buses, mobile and tracing lines around about, the same rhythms of the city, the same routes through the square, negotiating its islands of greenery and stock-still statues, while animals in the square travel in all directions - they have no concept of a path, a boundary, a square.

The hiss of pomegranates being squeezed interrupts my thoughts

I look up from my notepad

What do I see?

Nothing out of the ordinary - but what is ordinary?

Two pigeons simultaneously bob their heads and wander past - a ritual

It is cold. I order some rakija. 
I decide to move inside. But don't yet.

It is $12: 45$ p.m. - the bell tolls.

A child carrying a love heart balloon that floats in the breeze seems to provide a moment of poetic beauty on an otherwise grey day - pigeons gather around her little feet, drawn to the floating heart.

And two men carrying televisions on their backs in a sort of rucksack, provide a touch of the surreal, amongst the everyday humdrum flow of people along Ferhadija.

The mood of the square has changed

People walk faster - no longer strolling in the sun

The fully denim owner of the small stall that sells paintings, checks they are all still there The benches empty

The chess players play with minimal onlookers

The umbrellas outside all the cafés creak in the wind

Even the pigeons seem affected by the incoming gusts, scattering regularly.

The church bell tolls - it is one o'clock.

I am the only remaining customer at the café still sat outside.

Pomegranates are juiced - hiss, hiss, hiss.

A track-suited man now wears a thick overcoat 
He begins to move the toys and sunglasses into the little tunnel out of which his goods spill - though leaves the things that blow in the wind

A man with a map of the world walks past

And disappears down the tunnel - which I think allows access to Maršala Tita.

A duffel coat

A long dress that sways in the wind.

Hair blows into eyes and occasionally a hand brushes it away.

I see spots of rain

A soldier

Break.

\section{LOCATION: Svjetlostkomerc, Trg Oslobođenja}

DATE: Thursday $19^{\text {th }}$ May 2016

TIME: 3:40 p.m.

In the time since I was last writing I saw dancing-guy, regularly seen on Ferhadija jumping around for hours to techno music. He wears a headband attached to two balls on springs that bounce as he moves. A common sight, he has been dancing on Ferhadija for as long as people can remember. I also saw a young artist who paints on pieces of found wood, sticking other bits and pieces to the planks. He sells a few each day. 
I have taken cover beneath the window of a shop

The rain has started.

Leopard print umbrella $\quad$ Red umbrella

Black umbrella.

The men continue to play chess

One uses a piece of cardboard as a makeshift cover.

The knot of the city is emptying-out

People have returned to their homes

Retreated to a sanctuary away from the downpour

They will return I am sure.

Pink umbrella $\quad$ Blue umbrella with black stripes

Checkered umbrella $\quad$ Hooded man walking briskly

Several pigeons $\quad 1952-$ on a jumper.

The church bell tolls - it is 3:45 p.m.

A couple under an umbrella

A woman coughing under an umbrella.

Vauxhall Astra $\quad$ White Transit

Orange umbrella $\quad$ Silver VW Golf. 
Two women stood under a tree, shielded from the incoming gusts

And the rain falling from overhead.

A couple kiss, lips pursed

A car is starting nearby

Two police officers carry guns

Red Citroen
A trolley is pulled along

An umbrella is held at an odd angle

A man emerges from underground

A taxi.

The hiss of pomegranates being squeezed

Where is the speckled dog?

Black bishop takes white knight.

It is four o'clock

The bell tolls.

End.

\section{Corresponding author}

James Riding, Postdoctoral Researcher, Space and Political Agency Research Group/RELATE Centre of Excellence, University of Tampere, Pinni A, Kalevantie 4, 33100, Tampere, Finland. Email: james.riding@uta.fi 


\section{Funding}

This research was supported by the Leverhulme Trust: Leverhulme Early Career Research Fellowship, New Regional Geographies (For Sarajevo) [ECF 2013-638].

\section{Acknowledgements}

The author would like to thank supportive colleagues in the Department of Geography at the University of Sheffield, UK, and supportive members of the Space and Political Agency Research Group/RELATE Centre of Excellence, at the University of Tampere, Finland, the Leverhulme Trust for funding the wider project on which this article is based, Dr. Jessica Dubow and Dr. Igor Stiks for reading the article prior to submission, and the anonymous reviewers for their thoughful and constructive comments.

\section{Author biography}

James Riding is a Postdoctoral Researcher in the Space and Political Agency Research Group/RELATE Centre of Excellence, University of Tampere, Tampere, Finland. He was previously a Leverhulme Early Career Research Fellow in the Department of Geography at the University of Sheffield, Sheffield, UK, leading the project New Regional Geographies (For Sarajevo). He is the editor of Reanimating Regions: Culture, Politics, 
and Performance (2017), and the author of Land Writings: Excursions in the Footprints of Edward Thomas (2017).

\section{References}

Arsenijević, D. 2010. Forgotten future: the politics of poetry in Bosnia and Herzegovina. Baden-Baden: Nomos.

Arsenijević, D. 2011. Mobilising unbribable life: The politics of contemporary poetry in Bosnia and Herzegovina. In Towards a new literary humanism, ed. A. Mousley, 166-80. London: Palgrave Macmillan.

Arsenijević, D. ed. 2014. Unbribable Bosnia and Herzegovina: The struggle for the commons. Baden-Baden: Nomos.

Bellos, D. 1993. Georges Perec: A life in words. London: Harvill.

Benjamin, W. 2016. The storyteller. London: Verso.

Becker, H. 2001. George Perec's experiments in social description. Ethnography 2: 6376.

Bennett, C. 2016. Bosnia's paralysed peace. New York: Oxford University Press, Incorporated. 
Berger, J. 1972. Ways of seeing. London: Penguin.

Blanchot, M. 1989. The space of literature. Lincoln: University of Nebraska Press.

Bieber, F. 2006. Post-war Bosnia: Ethnicity, inequality and public sector governance. Hampshire: Palgrave Macmillan.

Calvino, I. 1974. Invisible cities. Orlando: Harcourt Brace Jovanovich.

Campbell, D. 1998. National deconstruction: Violence, identity, and justice in Bosnia. Minneapolis: University of Minnesota Press.

Campbell, D. 1999. Apartheid cartography: The political anthropology and spatial effects of international diplomacy in Bosnia. Political Geography 18: 395-435.

Carter, F.W. ed. 1977. An historical geography of the Balkans. London: Academic.

Cosgrove, D. 1985. Social formation and the symbolic landscape. Madison: University of Wisconsin Press.

Cosgrove, D. 2001. Apollo's eye: A cartographic genealogy of the earth in the Western imagination. Baltimore: John Hopkins University Press.

Cosgrove, D. 2008. Geography and vision: Seeing, imagining and representing the world. London: IB Taurus. 
Cosgrove, D. and Daniels, S. 1988. The iconography of landscape. Cambridge: Cambridge University Press.

Cosgrove, D. and Jackson, P. 1987. New directions in cultural geography. Area 19(2): 95-101.

Crampton, J. 1996. Bordering on Bosnia. GeoJournal 39(4): 353-361.

Cresswell, T. 2010. New cultural geography - an unfinished project? Cultural Geographies 17(2): 169-174.

Daniels, S. 2012. To the end of days: Narrating landscape and environment. Cultural Geographies 19(1): 3-9.

de Certeau, M. 1984. The practice of everyday life. Berkeley: University of California Press.

DeSilvey, C. 2006. Observed decay: Telling stories with mutable things. Journal of Material Culture 11(3): 318-338.

DeSilvey, C. 2007. Salvage memory: Constellating material histories on a hardscrabble homestead. Cultural Geographies 14(3): 401-424.

DeSilvey, C. 2010. Memory in motion: Soundings from Milltown, Montana. Social and Cultural Geography 11(5): 491-510. 
DeSilvey, C. 2012. Making sense of transience: An anticipatory history. Cultural Geographies 19(1): 30-53.

Dewsbury, J.D., Harrison, P., Rose, M. and Wylie, J. 2002. Enacting geographies. Geoforum 33(4): 437-440.

Dubow, J. 2001. Rites of passage: Travel and the materiality of vision at the Cape of Good Hope. In Contested landscapes: movement, exile and place, ed. B. Bender and M. Winer, 241-255. Oxford and New York: Berg.

Dubow, J. 2011. Still-life, after-life: W.G. Sebald and the demands of landscape. In Envisioning landscapes, making worlds: geography and the humanities, eds. S. Daniels S., D. DeLyser, J.N. Entrikin and D. Richardson, 188-198. London: Routledge.

Edensor, T. 2000. Walking in the British countryside. Body and Society 6(3-4): 81-106.

Edensor, T. 2005. The ghosts of industrial ruins: Ordering and disordering memory in excessive space. Environment and Planning D: Society and Space 23: 829-849.

Edensor, T. 2008. Mundane hauntings: Commuting through the phantasmagoric working class spaces of Manchester, England. Cultural Geographies 15: 313-333.

Garrett, B. 2013. Explore everything: Place-hacking and the city. London: Verso.

Glenny, M. 1992. The fall of Yugoslavia. London: Penguin. 
Glenny, M. 1999. The Balkans, 1804-1999: Nationalism, war and the great powers. London: Granta.

Goldsworthy, V. 1998. Inventing Ruritania: The imperialism of the imagination. London: Yale University Press.

Hemon, A. 2013. The book of my lives. London: Picador.

Hobbs, D. 2015. An attempt at an inexhaustible site in Lower Manhattan. Critical Military Studies 1(1): 88-98.

Horvat, S. and Štiks, I. eds. 2014. Welcome to the desert of post-socialism: Radical politics after Yugoslavia. London: Verso.

Ingold, T. 1993. The temporality of the landscape. World Archaeology 25: 152-174.

Jeffrey, A. 2006. Building state capacity in post-conflict Bosnia and Herzegovina: The case of Brčko District. Political Geography 25: 203-227.

Jeffrey, A. 2012. The improvised state: sovereignty, performance and agency in Dayton Bosnia. London: Wiley Blackwell.

Jergović, M. 2004. Sarajevo Marlboro. Brooklyn, NY: Archipelago Books.

Jones, O. 2005. An emotional ecology of memory, self and landscape. In Emotional geographies, eds. J. Davidson, L. Bondi and M. Smith, 205-218. Oxford: Ashgate. 
Lefebvre, H. 2004. Rhythmanalysis: Space, time, and everyday life. London: Continuum.

Little, A. and Silber, L. 1996. The death of Yugoslavia. London: Penguin.

Lorimer, H. 2003. Telling small stories: Spaces of knowledge and the practice of geography. Transactions of the Institute of British Geographers 28(2): 197-217.

Lorimer, H. 2006. Herding memories of humans and animals. Environment and Planning D: Society and Space 24: 497-518.

Lorimer, H. 2012. Memoirs for the Earth: Jacquetta Hawkes's literary experiments in deep time. Cultural Geographies 19(1): 87-106.

Lorimer, H. and Wylie, J. 2010. Loop (a geography). Performance Research 15(4): 6-13.

Maddrell, A. and Sidaway, J. 2010. Deathscapes: Spaces for death, dying, mourning and remembrance. London: Routledge.

Matless, D. 2008. A geography of ghosts: The spectral landscapes of Mary Butts. Cultural Geographies 15(3): 335-358.

Matless, D. 2010. Describing landscape: Regional sites. Performance Research 15(4): 72-82.

Matless, D. 2014. In the nature of landscape: Cultural geography on the Norfolk Broads. London: Wiley Blackwell. 
Mazower, M. 2002. The Balkans: From the end of Byzantium to the present day. London: Phoenix.

Nancy, J-L. 2000. Being singular plural. Stanford. California: Stanford University Press.

Pearson, M. 2006. "In comes I”: Performance, memory, and landscape. Exeter: University of Exeter Press.

Perec, G. 2008. Species of spaces and other pieces. London: Penguin Classics.

Perec, G. 2010. An attempt at exhausting a place in Paris. New York: Wakefield Press.

Perec, G. 2014. Portrait of a man. Chicago: University of Chicago Press.

Perec, G. 2016. L'Attentat de Sarajevo. Paris: Seuil.

Phillips, R. 2016. George Perec's experimental fieldwork; Perecquian fieldwork. Social and Cultural Geography. Advance online publication.

Riding, J. 2015a. Landscape, memory, and the shifting regional geographies of northwest Bosnia-Herzegovina. GeoHumanities 1(2): 378-397.

Riding, J. 2015b. Death drive: Final tracings. In Geographical aesthetics: Imagining space, staging encounters, eds. H. Hawkins and E. Straughan, 181-196. Farnham: Ashgate. 
Riding, J. 2016a. A new regional geography of a revolution: Bosnia's plenum movement. Territory, Politics, Governance. Advance online publication.

Riding, J. 2016b. A geographical biography of a nature writer. Cultural Geographies 23(3): 387-399.

Riding, J. 2016c. Geographical testimony: A short history of a Yugoslav family. Journal of Cultural Geography. Advance online publication.

Riding, J. 2017. Representing a divided place: The artistic-military practice of Mladen Miljanović. Cultural Geographies 24(1): 171-180.

Rieff, D. 1995. Slaughterhouse: Bosnia and the failure of the West. London: Vintage Random House.

Rose, M. 2006. Gathering 'dreams of presence': A project for the cultural landscape. Environment and Planning D: Society and Space 24: 537-554.

Rose, M. 2012. Dwelling as marking and claiming. Environment and Planning D: Society and Space 30(5): 757-771.

Sontag, S. 2004. Regarding the pain of others. London: Penguin Books.

Stoker, B. 1897. Dracula. Westminster: Archibald Constable and Company. 
Taussig, M. 2006. Walter Benjamin's grave. Chicago: University of Chicago Press.

Thompson, M. 1992. A paper house: The ending of Yugoslavia. London: Vintage.

Thrift, N. 2008. Non-representational theory: Space, politics, affect. Oxford: Routledge.

Till, K. 2005. The New Berlin: Memory, politics, place. Minneapolis: University of Minnesota Press.

Till, K. 2010. Mapping spectral traces. In Mapping spectral traces, ed. K. Till, 1-4. Blacksburg, VA: Virginia Tech College of Architecture and Urban Affairs.

Tilley, C. 1994. A phenomenology of landscape: Places, paths, and monuments. Oxford: Berg.

Toal, G. 1996. An anti-geopolitical eye: Maggie O'Kane in Bosnia, 1992-93. Gender, Place and Culture 3(2): 171-186.

Toal, G. and Dahlman, C. 2011. Bosnia remade: ethnic cleansing and its reversal. Oxford: Oxford University Press.

Todorova, M. 1997. Imagining the Balkans. Oxford: Oxford University Press

Wylie, J. 2002. An essay on ascending Glastonbury Tor. Geoforum 33: 441-454. 
Wylie, J. 2005. A single days walking: Narrating self and landscape on the South West Coast Path. Transactions of the Institute of British Geographers 30: 37-51.

Wylie, J. 2007. Landscape. London: Routledge.

Wylie, J. 2009. Landscape, absence, and the geographies of love. Transactions of the Institute of British Geographers 34: 275-289.

Žižek, S. 2000. The fragile absolute: Or why is the Christian legacy worth fighting for? London: Verso. 